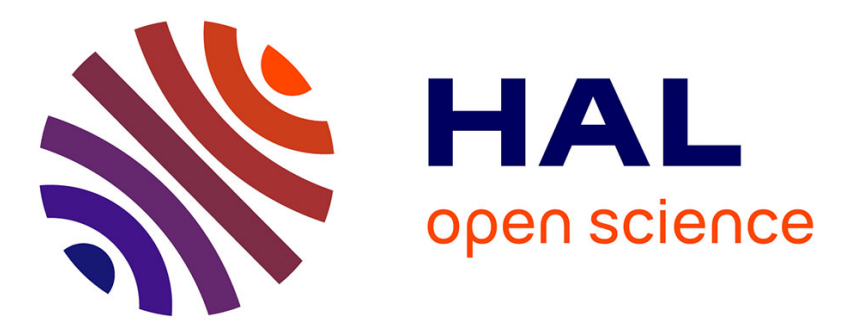

\title{
INTERACTION BETWEEN ARGON AND DOPANTS IN SPUTTERED a-Si : $\mathrm{H}$
}

M. Toulemonde, J. Grob, J. Bruyère, A. Deneuville, H. Hamdi, P. Siffert

\section{To cite this version:}

M. Toulemonde, J. Grob, J. Bruyère, A. Deneuville, H. Hamdi, et al.. INTERACTION BETWEEN ARGON AND DOPANTS IN SPUTTERED a-Si: H. Ninth International Conference on Amorphous and Liquid Semiconductors, 1981, Grenoble, France. pp.C4-799-C4-801, 10.1051/jphyscol:19814175 . jpa-00220800

\section{HAL Id: jpa-00220800 https://hal.science/jpa-00220800}

Submitted on 1 Jan 1981

HAL is a multi-disciplinary open access archive for the deposit and dissemination of scientific research documents, whether they are published or not. The documents may come from teaching and research institutions in France or abroad, or from public or private research centers.
L'archive ouverte pluridisciplinaire HAL, est destinée au dépôt et à la diffusion de documents scientifiques de niveau recherche, publiés ou non, émanant des établissements d'enseignement et de recherche français ou étrangers, des laboratoires publics ou privés. 


\title{
INTERACTION BETWEEN ARGON AND DOPANTS IN SPUTTERED a-SI:H
}

\author{
M. Toulemonde, J.J. Grob, J.C. Bnuyère , A. Deneuville* , H. Hamdi ${ }^{*}$ and P. \\ Siffert \\ Centre de Recherches Nucléaires, Groupe de Physique et Applications des \\ Semiconducteurs (PHASE), 67037 Strasbourg Cedex, France \\ * Groupe des Transitions de phases, C.N.R.S., 38042 Grenoble Cedex, France
}

\begin{abstract}
The concentrations of As, B, H, Ar and Si in sputtered a-Si:H are measured by helium Rutherford backscattering and nuclear reactions analysis. Excess or deficit of hydrogen and argon by comparison with intrinsic a-Si:H are found in presence of dopants at high deposition rate. This is related to the plasma deposition method and would suggest micro grain structure in the deposited layer.
\end{abstract}

Introduction. - In making sputtered amorphous silicon it is impossible to avoid the presence of argon. In contrary to hydrogen, the role of which is understood $(1,2,3,4)$, the argon was always considered as inactive. In the present work the variation of Ar concentration in intrinsic a-Si:H and doped a-Si:H will be determined and the possible interactions with other species of the matrix will be discussed in term of amorphous structure.

Experimental methods. - The samples used in this study, were prepared at $190^{\circ} \mathrm{C}$ by rf cathodic sputtering of a silicon target with different combinations of three reactive gas mixtures at a total pressure of $9 \times 10^{-3}$ torr. The pourcentage of diborane has varied in order to prepare different samples with different concentration of boron. The substrate target holder were kept at values corresponding to deposition rate between $20 \AA / \mathrm{mn}$ to $150 \AA / \mathrm{mn}$. Each sample was deposited on a $100 \Omega \mathrm{c}-\mathrm{Si}$ and their thicknesses have been measured by interference fringes.

Ar and Si concentration was deduced from Rutherford backscattering measurements. Hydrogen was profiling using the $\mathrm{H}\left(15_{\mathrm{N}}, \alpha\right){ }^{12} \mathrm{C}$ reaction $(1,5)$ and the boron profiling and/or concentration were deduced from $" \mathrm{~B}(\mathrm{p}, \alpha)^{8} \mathrm{Be}$ reaction at $\mathrm{E}_{\mathrm{p}}=$ $163 \mathrm{kev}(6,5)$.

Results and discussions.

Intrinsic a-Si:H. The results are show on fig. 1 where the evolution of $A r, H$ and $\mathrm{Si}$ versus the deposition rate axe reported. These values are determined by comparison to the number of atoms in a crystalline silicon. The argon concentration at $200 \AA / m n$ has been determined at Montreal (J.C. Bruyère et al. private communication). The first remark is an inverse evolution of the $E$ and Ar compared to the silicon, more silicon inhibits the introduction of argon and hydrogen. The second remark is the two order of magnitude change in the spin density measurement (7). Moreover at high deposition rate a posthydrogenation did not change the number of spin. Consequently it seems that the dense matrix did not allow the diffusion of hydrogen towards the existing defects when after the deposition. As in a glow discharge preparation even for a dense matrix the number of spin does not kept so high values ( 8 ), it appear that the inclusion of argon inhibits the possibility of the hydrogen to saturate the existing defects. 
Doped a-Si:H. The fig. 2 shows the evolution of $\mathrm{B}$ and $\mathrm{H}$ as a function of the initial gas mixture. The dopant efficiency is around 55 at low deposition rate and 12 at high. At low boron concentration, the hydrogen concentration reach the one determined in intrinsic a-Si:H. This incorporation is identical to that of arsenic (10). Now concentrate our purpose on samples prepare at high deposition rate (130 $\AA / \mathrm{min}$ ) and high doping level. The direct link between dopants ( $B, P$ and As), and hydrogen has been shown previously $(9,10,11)$. Moreover on the following table we can see that the argon concentration is low in

Table 1 : mean concentration ( 8 )

$\begin{array}{cccr} & \text { dopants } & \text { H } & \text { Ar } \\ \text { n layer (As) } & 5 & 13 & 1 \\ \text { p layer (B) } & 5 & 4 & 7\end{array}$

the $\mathrm{n}$ layer compare to intrinsic a-Si: $K$ and high in the $p$ layer. As, when dopants are implant in amorphous a-Si:H the hydrogen concentration is not influenced in the same manner (F.J. Demond et al. private communication) the variation of hydrogen and argon should follow the amorphous nucleation during the deposition.

One possible explanation would suggest that the nucleation proceeds by microscopic amorphous grain (4), the dopants standing mainly at the surface of the grain. Indeed this could explain that at grain boundaries it is possible to add argon atom when there is no hydrogen as it is the case with boron and the contrary with arsenic. As there is less hydrogen with boron dopant, this would suggest that boron act as defects passivation. These defects could be in the volume of the amorphous grain and not at the surface, but it would be then difficult to add more argon, except at the grain boundary since hydrogen linked to the silicon would stand here.

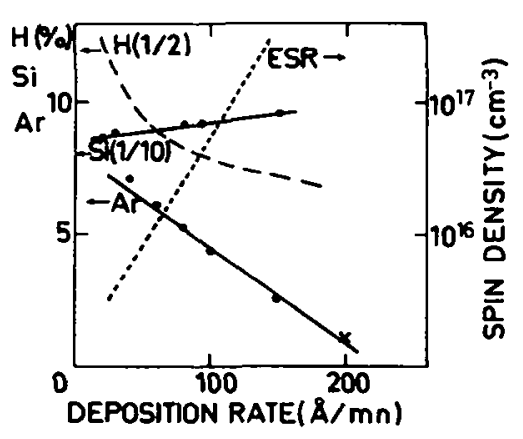

Fig. 1 : H, Si, Ar concentration (z) and spin density $\left(\mathrm{cm}^{-3}\right)$

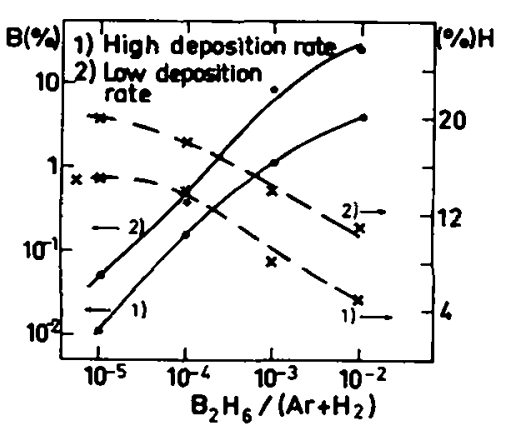

Fig. 2 : $B$ and hydrogen incorporation as function of gas mixture for high and low deposition rate 


\section{References}

1. BRODSKY M.H., FRISH M.A., ZEIGLER J.F. and LANFOPD W.A., Appl. Phys. Lett. 30 (1977) 561.

2. CLARK G.J., WHITE C.W., ALLRED D.D., APPLETON B.R., KOCH F.B. and MAGEE C.V., Nucl. Instr. Meth. $149(1978) 9$.

3. PERRIN J., SOLOMON I., BOURDON B., FONTENILIE Y, and LIGEON E., Thin Solid Films 62 (1979) 327.

4. DENEUVIlle A., BRUYERE J.C., MINI A., KAHIL H., DANIELOU R. and LIGEON E., J. Phys. C 14 (1981) 2279 .

5. TOULEMONDE M., GROB J.J., SIFFERT P., DENEUVILIE A, and BRUYERE J.C., in "Nuclear Physics Methods in materials research" E.P.S. Neeting p. 340 , (Darmstadt 1980).

6. LIGEON E. and BONTEMPS A. J. of Rad. Chem. 12 (1972) 335.

7. KAMDI H, DENEUVILLE A. And BRUYERE J.C., J. Phys. Lett. 41 (1980) I 483 .

8. LUCOVSKI G., NEMANICH R.J., KNIGHTS J.C., Phys. Rev. B19 (1979) 2064.

9. TOULEMONDE M., SIFFERT P., DENEUVILLE A., BRUYERE J.C., Appl. Phys, Lett. (in press).

10. DENEUVILLE A., BRUYERE J.C., TOULEMONDE M., GROB J.J. and SIFFERT P., "Tetrahedrally bonded amorphous semiconductors" Carefree (USA) mars 1981.

11. MULLER G., DEMOND F.J. KALBITZER S., DAMJANTSCHITSCH H., MANNSPERGER H., SPEAR W.E., LE COMBER P.G. and GIBSON R.A., Phil. Mag. 41B (1980) 571 . 